DOI:

Василь Сіладі, аспірант, спецііальність 015 “Професійна освіта” (за спеціалізаціями), Мукачівського державного університету

\title{
РІЗНОМАНІТНІСТЬ ПІХОДІВ ДО ІНШОМОВНОЇ ПІДГОТОВКИ В ЄВРОПЕЙСЬКОМУ ОСВІТНЬОМУ СЕРЕДОВИЩІ
}

У статті здійснено аналіз підходів до іншомовної підготовки в сучасному європейському освітньому середовищі. Виокремлено аспекти комплексного підходу до вивчення іноземних мов: багатомовність у школах та установах професійної підготовки і навчання; ефективне і новаторське викладання для поглибленого вивчення мови; підтримка вчителів і тренерів; партнерські відносини і зв 'язки в шкільному середовищі для підтримки вивчення мови. Зроблено висновок, щзо іншомовна підготовка сьогодні розглядається не просто як передача і накопичення знань, а як формування ключових компетенцій, які підготували б людину до реальноі професійної діяльності в мультикультурному суспільстві. Іноземна мова сьогодні є важливим чинником успішного кар'єрного зростання, а вміння спілкуватися в письмовій та усній формі рідною й іноземною мовами є вимогою до професійної компетенції висококваліфікованого працівника у будь-якій галузі.

Ключові слова: іноземна мова; іншомовна підготовка; Загальноєвропейські рекомендачії з мовної освіти.

Puc. 1. Jim. 9.

Vasyl Siladi, Postgraduate Student Specialty 015 "Professional education" (by specializations), Mukachevo State University

\section{DIVERSITY OF APPROACHES TO FOREIGN LANGUAGE TRAINING IN THE EUROPEAN EDUCATIONAL ENVIRONMENT}

The article analyses the approaches to foreign language training in the modern European educational environment. The aspects of a comprehensive approach to the study of foreign languages are highlighted: multilingualism in schools and institutions of vocational training and education; an effective and innovative teaching for in-depth language learning; support for teachers and trainers; partnerships and connections in the school environment to support language learning. It is emphasized that a positive attitude towards linguistic diversity can help to create a favourable language environment in which the study and use of several languages will be perceived as a wealth and a resource. An emphasis is placed on the connection between everyday language practice and schools or vocational schools, which can be strengthened in the process of non-formal learning. The experience of cooperative learning is valuable, in the process of which students can help each other in learning, and explain the features of foreign meanings and concepts. It is important for foreign language training and social integration to establish partnerships between educational institutions in the regions in particular border regions, which can encourage children to learn the language of the neighbouring country from an early age and thus reduce language barriers. It is noted that the possibilities of digital tools should be used to improve foreign language learning, teaching and assessment. Teachers of modern languages should be encouraged to participate into exchange programs with the countries where they speak the languages being studied, as part of their initial training and/or further professional development. Vocational education and training schools and institutions can work with parents to support the children's learning of foreign languages, especially if the children live in a multilingual family. It is concluded that foreign language training today is considered not just as the transfer and accumulation of knowledge, but as the formation of key competencies that would prepare a person for real professional activity in a multicultural society. Today, a foreign language is an important factor in successful career growth, and the ability to communicate in writing and orally in native and foreign languages is a requirement for the professional competence of a highly qualified worker in any field. education

Keywords: foreign language; foreign language training; Pan-European recommendations on language

$\Pi$

остановка проблеми. Сучасне європейське суспільство зазнає швидких змін, пов'язаних 3 глобалізацією, технологічним прогресом, розширенням і поглибленням інтеграції. Значною стала внутрішньоєвропейська мобільність: сьогодні понад 10 млн європейців працюють в інших країнах членах ЄС. Відповідно до цих та інших чинників життя громадян СС стає більш інтернаціональним, мультикультурним та різномовним.

Необхідність комунікації у багатомовному середовищі вимагає визначення певних принципів та правил, реалізації організаційних і технічних 


\section{РІЗНОМАНІТНІСТЬ ПІДХОДІВ ДО ІНШОМОВНОЇПІДГОТОВКИ В ЄВРОПЕЙСЬКОМУ ОСВІТНЬОМУ СЕРЕДОВИЩІ}

заходів, які дали б можливість існувати й розвиватися як самому об'єднанню, так і окремим його членам. У європейському соціальному середовищі зростає розуміння того, що розвиток економічної, соціальної та культурної інтеграції вимагає вищого рівня лінгвістичної гармонії. Адже серед національних мовних просторів у світі одномовних $є$ набагато менше, ніж багатомовних [6].

На досягнення цієї мети спрямована політика у сфері навчання іноземних мов, яку можна виділити як окремий напрям мовної політики $Є \mathrm{C}$, що передбачає сприяння вивченню іноземних мов у європейських країнах. Для контролю за реалізацією мовної політики СС вводяться такі “індикатори лінгвістичної компетентності”, як загальноєвропейське тестування дітей до 16 років на знання найпоширеніших у СС іноземних мов, проведення європейських оглядів мовної компетенції [5] тощо.

Аналіз останніх досліджень і публікацій. Вивченню мовної ситуації й ролі мовного питання, а також окремим аспектам багатомовної політики Європейського Союзу присвячено чимало наукових досліджень, серед яких першочергової ваги набувають питання політичного аспекту мовної ситуації, а також проблеми формування міжкультурної компетенції, які в системі освіти XXI ст. були виокремлені як пріоритетні, формування відкритої і творчої особистості 3 полікультурним світоглядом, яка може здійснювати безконфліктну взаємодію міжкультурної комунікації з метою професійного і особистісного розвитку. Значну увагу приділено питанням іншомовної підготовки, оскільки вивчення мови стає важливим елементом всіх навчальних предметів.

Так, Г. Поліщук на основі аналізу теоретичних праць вітчизняних і зарубіжних фахівців довела, що пошук взаємоприйнятних способів урегулювання міжнаціональних конфліктів, консенсусу у розв'язанні проблеми; застосування сучасних технологій залагодження педагогічних конфліктів у закладах освіти, володіння методик майбутніми вчителями іноземних мов відкриває нові шляхи попередження міжнаціональних конфліктів, що виступає конструктивною технологією створення безпечного і толерантного середовища успішної соціалізації дітей і молоді $[4$, 70]. О. Малюга звертає увагу на важливість професійно орієнтованого і комунікативного підходів у вивченні іноземної мови і зауважує, що “однією $з$ цілей, яку ставить перед собою викладач, є формування особистості, готової до саморегуляції, і досягнення цієї мети стає можливим при перенесенні акценту з навчальної діяльності на пізнавальну. Водночас автор підкреслює, що результатом застосування таких педагогічних практик стає стимуляція роботи кожного окремого суб'єкта освітнього процесу, заснованої на розвитку творчої діяльності та ініціативності” $[3,121]$.

У. Кецик-Зінченко закцентувала увагу на особливостях професійно-орієнтованого навчання іноземної мови студентів немовних спеціальностей, що у мультикультурному середовищі дає можливість диференційованого підходу до пошуку і добору навчального матеріалу з метою використання його у процесі професійної комунікації $[2,102]$. О. Троценко також наголошує на необхідності оновлення підготовки вчителів 3 урахуванням іншомовної компоненти та перспективності включення до освітнього процесу нових технологій, зокрема педагогічного моделювання [9, 206-207].

Чимало досліджень присвячено проблемі іншомовної підготовки в європейських країнах. Так, Ю. Талалай звертає увагу на проблему модернізації навчання іноземним мовам у старшій школі країн Центральної Свропи в умовах мультилінгвізму [8]. А. Соломаха, О. Лобода вказують, що в глобалізованому суспільстві навчання іноземних мов продовжує відігравати важливу роль у формуванні висококультурної та конкурентоспроможної особистості, здатної не тільки успішно здійснювати пошук потрібної інформації, а й реалізовувати свою соціальну й професійну мобільність у процесі міжкультурного спілкування. Інтеграція України до європейського освітнього простору, своєю чергою, потребує розширення діапазону іншомовних професійних умінь майбутніх фахівців у сфері освіти [7]. У “Загальноєвропейських Рекомендаціях з мовної освіти: вивчення, викладання, оцінювання" [1] та “Європейському мовному портфоліо” ELP (European Language Portfolio) визначено шляхи розвитку іншомовної освіти.

Мета статті: здійснити аналіз підходів до іншомовної підготовки в сучасному європейському освітньому середовищі.

Виклад основного матеріалу. Зазначимо, що у 2019 р. Радою Європи прийнято Рекомендації "Про комплексний підхід до викладання і вивчення мов” [5], в яких підкреслюється, що тільки врахування різних чинників впливу на формування іншомовної компетентності може сприяти успішному оволодінню іноземною мовою. Визначено аспекти такого комплексного підходу, які відображено на рис. 1.

Насамперед звернемо увагу на врахуванні 


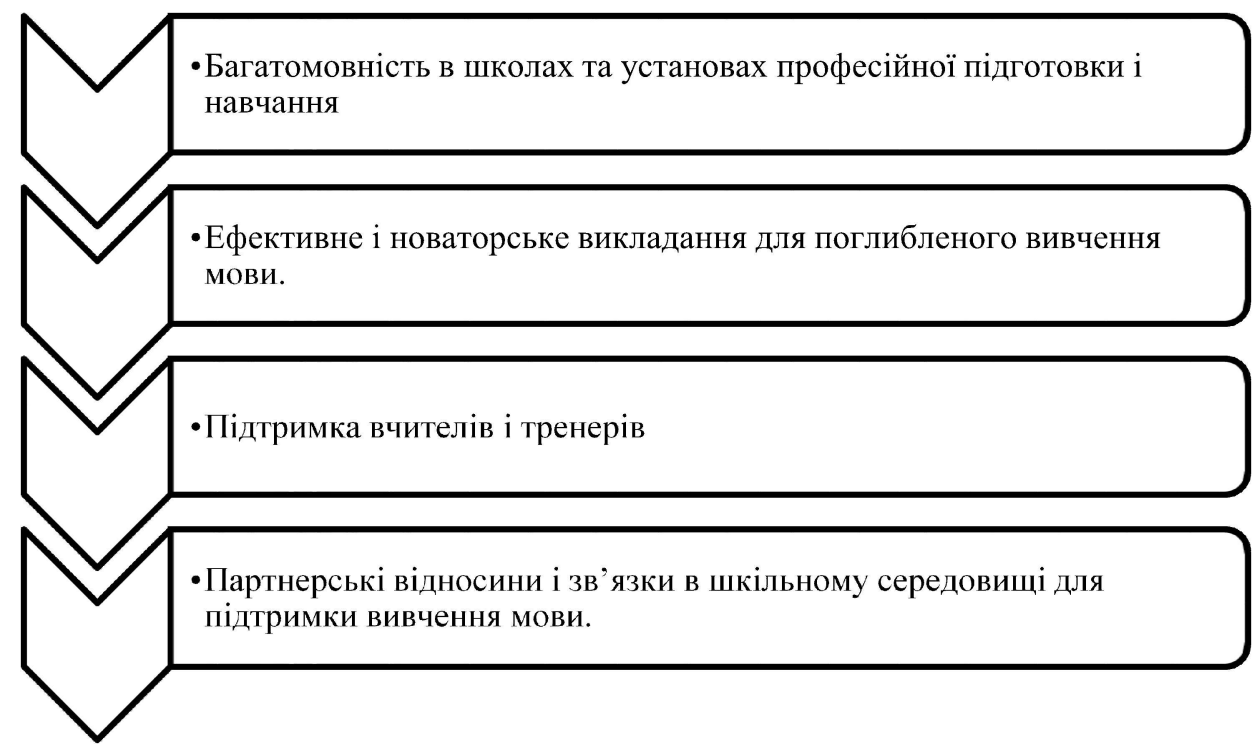

Рис. 1. Аспекти комплексного підходу до викладання і вивчення мов в європейському освітньому середовищі

такого аспекту, як багатомовність в школах та установах професійної підготовки і навчання. У “Загальноєвропейських рекомендаціях з мовної освіти: вивчення, викладання, оцінювання” [1] підкреслюється, що позитивне ставлення до мовного розмаїття може допомогти створити сприятливе мовне середовище, в якому вивчення і використання декількох мов буде сприйматися як багатство і ресурс. При цьому розуміння важливості вивчення мови і освітніх, пізнавальних, соціальних, міжкультурних, професійних i економічних переваг більш широкого використання мов може бути підвищено і повинно заохочуватися. Рекомендується розвиток мовної компетенції та мовної обізнаності трансверсально інтегрувати в навчальні програми, застосувати автентичне навчання, орієнтоване на реальні життєві ситуації, задля інтеграції мов. Мотивацію учнів до вивчення мов можна підвищити, пов' язавши освітній контент з їх власним життям й інтересами, беручи до уваги неформальне навчання i заохочуючи взаємодію у позааудиторних заняттях. Наголошується на особливостях зв'язку між повсякденною мовною практикою і школами або професійно-технічними закладами освіти, які можна зміцнити у процесі неформального навчання. Цінним є досвід кооперативного навчання, у процесі якого учні можуть допомагати один одному в навчанні, пояснювати особливості іншомовних значень і понять. Прийняття іноземної мови учнем буде різним залежно від того, чи є в країні дві або більше державних мови або чи є заявлений інтерес до просування вивчення мови сусідньої країни.
Безперечно, важливим для іншомовної підготовки та соціальної інтеграції є встановлення партнерських відносин між освітніми закладами регіонів, зокрема прикордонних регіонів, які можуть заохочувати дітей до вивчення мови сусідньої країни, починаючи з раннього віку i, отже нівелюючи мовні бар'єри [1]. Окрім того, актуальним залишається подальше заохочення шкіл і закладів професійної освіти і навчання до використання європейського мовного етикету для заохочення вивчення мов та мовної різноманітності, врахування етикетних особливостей комунікації для просування європейської перспективи розвитку закладів освіти і навчальних центрів.

Другим аспектом рекомендацій є ефективне $i$ новаторське викладання для поглибленого вивчення мови [1]. Зазначено, що для поліпшення вивчення іноземної мови, викладання та оцінювання необхідно використовувати можливості цифрових інструментів. Технології можуть значною мірою сприяти розширенню мовної пропозиції, надавати можливості для вивчення мов і бути дуже корисними для підтримки розвитку тих мов, які не викладаються у школах. Як новаторський напрям у викладанні, можуть бути застосовані технології розвитку критичного мислення та медіаграмотності. Віртуальне співробітництво між школами за допомогою eTwinning й інших форм віртуального співробітництва надасть кращі можливості молодим людям для вивчення мови, комунікації $з$ однолітками 3 інших країн та сприятиме мобільності для навчання, стажування або 


\section{РІЗНОМАНІТНІСТЬ ПІДХОДІВ ДО ІНШОМОВНОЇПІДГОТОВКИ В ЄВРОПЕЙСЬКОМУ ОСВІТНЬОМУ СЕРЕДОВИЩІ}

волонтерської діяльності за кордоном. Мобільність учнів, у тому числі через Erasmus +, могла б стати регулярною частиною процесу навчання. Це має поширюватися на віртуальну мобільність персоналу. Вчителі, інструктори та учні можуть використовувати поєднання діагностичної, формувальної і підсумкової оцінки для моніторингу та оцінювання мовного розвитку, а також індивідуальні мовні портфелі для відстеження прогресу, наприклад, за допомогою Європейського мовного портфеля або мовного паспорта Europass.

Третій аспект рекомендацій - підтримка вчителів $і$ тренерів. Вчителів сучасних мов необхідно заохочувати до участі в програмах обміну з країнами, де розмовляють на тих мовах, які вивчаються, у рамках їх початкової підготовки i/або подальшого професійного розвитку. Для кожного учителя, який недавно закінчив навчання за професійною підготовкою, рекомендується продовжити навчання впродовж семестру в рамках професійного розвитку з метою отримання знань мови і знань з лінговодидактики та проєктування стратегії підтримки учнів.

Можливості безперервного професійного розвитку можуть бути доступні для вчителів через інформаційні освітні мережі, спільноти практикуючих вчителів іноземних мов, масові мовні онлайн-курси, центри експертизи, спільного онлайн-навчання, спільної дослідницької діяльності тощо.

Четвертий аспект - партнерські відносини $i$ зв'язок у шкільному середовищі для підтримки вивчення іноземної мови. В рекомендаціях наголошується, що школи та установи професійної освіти і навчання можуть співпрацювати з батьками в підтримці навчання дітей іноземних мов, особливо якщо діти проживають в мультимовній родині. Школи та установи професійної освіти і навчання можуть налагоджувати партнерські відносини з мовними центрами / мовними лабораторіями, публічними бібліотеками, культурними центрами або іншими культурними асоціаціями, університетами та дослідницькими центрами, щоб створити більш привабливе освітнє середовище, збагатити вивчення мов і поліпшити інноваційну педагогічну практику.

Ще одним важливим чинником є співпраця 3 роботодавцями в регіоні або за його межами, що може допомогти у формуванні політики багатомовної компетентності в професійній діяльності та гарантією працевлаштування [7; 8]. Можна заохочувати транскордонне партнерство між освітніми закладами в прикордонних регіонах.
Вартим уваги є створення курсів на іноземній мові в країні, яка є прикордонною, для студентів, викладачів, інструкторів та адміністративного персоналу, а також докторантів і дослідників, що сприятиме транскордонній співпраці й підготовці конкуретоспроможних випускників до виходу на ринок праці по обидва боки кордону.

Висновки та перспективи подальших досліджень. Іншомовна підготовка сьогодні розглядається не просто як передача i накопичення знань, а як формування ключових компетенцій, які підготували б людину до реальної професійної діяльності в мультикультурному суспільстві. Іноземна мова сьогодні є важливим чинником успішного кар'єрного зростання, а вміння спілкуватися в письмовій та усній формі рідною та іноземною мовами - вимогою до професійної компетенції висококваліфікованого працівника у будь-якій галузі.

Перспективами подальших досліджень можуть бути сучасні освітні технології навчання іноземних мов та побудова траєкторії індивідуального іншомовного навчання фахівця.

\section{ЛІТЕРАТУРА}

1. Загальноєвропейські рекомендації з мовної освіти: вивчення, викладання, оцінювання. URL: https://lenvit.ucoz.ua/ZER.pdf

2. Кецик-Зінченко У. Особливості професійноорієнтованого навчання іноземної мови студентів немовних спеціальностей. Молодь і ринок. 2019. № 9 (176). С. 101-106.

3. Малюга Е.Н. Метод проектов в обучении профессиональной коммуникации на иностранном языке в рамках МООК. Вестник МГОУ. Педагогика. 2016. № 4. С. 119 - 124.

4. Поліщук Г. Педагогічний потенціал медіації у професійній підготовці майбутніх учителів іноземної мови. Молодь і ринок. 2020. № 3(181). C.70-74.

5. О комплексном подходе к преподаванию и изучению языков. Рекомендация Совета от 22 мая 2019 г. (2019 / C 189/03) https://eur-lex. europa.eu/legal-content/ EN/TXT/?uri=uriserv \%3AOJ.C 2019.189.01.0015.01. ENG\&toc $=\mathrm{OJ} \% 3 \mathrm{AC} \% 3 \mathrm{~A} 2019 \% 3 \mathrm{~A} 189 \% 3 \mathrm{~A}$ TOC

6. Селіванова О. О. Лінгвістична енциклопедія. Полтава: Довкілля-К, 2010. 844 с.

7. Соломаха А.В., Лобода О.В. Сучасні тенденції іншомовної підготовки майбутніх учителів початкової ланки освіти Угорщини. Інноваційна педагогіка. 2020. Випуск 24. Т.2. C.119- 124 .

8. Талалай Ю. Модернізації навчання іноземних мов у старшій школі країн Центральної Свропи в 
умовах мультилінгвізму. Автореферат дисертації на здобуття наукового ступеня кандидата педагогічних наук за спеціальністю 13.00.04; Дрогобицький державний педагогічний університет імені Івана Франка. Дрогобич, 2017. $23 \mathrm{c}$.

9. Троценко О.Я. Педагогічне моделювання професійної підготовки майбутніх учителів іноземної мови початкової школи: дис. канд. пед. наук: спец. 13.00.04; Київський університет імені Бориса Грінченка. Київ, 2012. 308 с.

\section{REFERENCES}

1. Zahalnoievropeiski rekomendatsii $\mathrm{z}$ movnoi osvity: vyvchennia, vykladannia, otsiniuvannia. [European recommendations for language education: study, teaching, assessment]. Available at: https:// lenvit.ucoz.ua/ZER.pdf [in Ukrainian].

2. Ketsyk-Zinchenko, U. (2019). Osoblyvosti profesiino-oriientovanoho navchannia inozemnoi movy studentiv nemovnykh spetsialnostei [Features of professionally-oriented foreign language teaching of students of non-language specialties]. Youth and the market. No. 9 (176). pp. 101-106. [in Ukrainian].

3. Malyuga, E. H. (2016). Metod proektov v obuchenii professionalnoj kommunikaczii na inostrannom yazyke v ramkakh MOOK [Method of projects in teaching professional communication in a foreign language within the framework of MOOC]. MGOU Bulletin. Pedagogy. No. 4. pp. $119-124$. [in Russian].

4. Polishchuk, G. (2020). Pedahohichnyi potentsial mediatsii u profesiinii pidhotovtsi maibutnikh uchyteliv inozemnoi movy [Pedagogical potential of mediation in the training of future foreign language teachers].
Youth and the market. No. 3 (181). pp.70-74. [in Ukrainian].

5. O kompleksnom podkhode k prepodavaniyu i izucheniyu yazykov. Rekomendacziya Soveta ot 22 maya 2019 g. (2019 / C 189/03) [About an integrated approach to teaching and learning languages. Council Recommendation 22 May 2019 (2019 / C 189/03)]. Available at: https://eur-lex. europa.eu/legal-content/ EN/TXT/?uri=uriserv\%3AOJ.C_2019.189.01.0015 .01 . ENG \& toc $=\mathrm{OJ} \% 3 \mathrm{AC} \% 3$ A2019 \%3A189 $\% 3$ ATOC [in Russian].

6. Selivanova, O.O. (2010). Linhvistychna entsyklopediia [Linguistic encyclopedia]. Poltava, 844 p. [in Ukrainian].

7. Solomakha,A.V. \& Loboda, O.V.(2020). Suchasni tendentsii inshomovnoi pidhotovky maibutnikh uchyteliv pochatkovoi lanky osvity Uhorshchyny [Current trends in foreign language training of future primary school teachers in Hungary]. Innovative pedagogy. Issue 24. Vol.2. pp.119-124. [in Ukrainian].

8. Talalai,Y. (2017). Modernizatsii navchannia inozemnykh mov u starshii shkoli krain Tsentralnoi Yevropy v umovakh multylinhvizmu [Modernization of foreign language teaching in high school in Central Europe in the context of multilingualism]. Extended abstract of candidate's thesis. Ivan Franko Drohobych State Pedagogical University. Drogobich, 23 p. [in Ukrainian].

9. Trotsenko, O.Ya. (2012). Pedahohichne modeliuvannia profesiinoi pidhotovky maibutnikh uchyteliv inozemnoi movy pochatkovoi shkoly [Pedagogical modeling of professional training of future teachers of a foreign language of primary school]. Candidate's thesis. Borys Hrinchenko University of Kyiv. Kyiv, 308 p. [in Ukrainian].

Стаття надійшла до редакції 15.01.2021

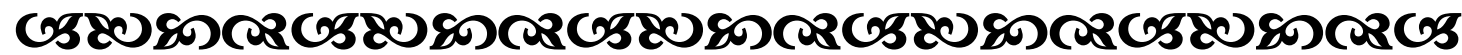

"Корисним для себе ( $і$ для суспільства) буде тільки той, хто пізнав свою природу. ТТоді людина розуміє свою місію. Своє покликання на землі й виробляе для себе спосіб життя, в основі яқого лежить “споріднена праия". ТІіььц так людина може самоствердитися і самореалізуватися, а значить стати щасливою".

Тригорій Сковорода уқраӥнський просвітитель-гуманіст, ббілособ, поет, педагог

Будь-яқе навчання людини, є не що інше, як мистецтво сприяти прагненню природи до свого власного розвитку".

ҮัҮоганн Тенріх Лесталоииі видатний швейцарський педагог-новатор

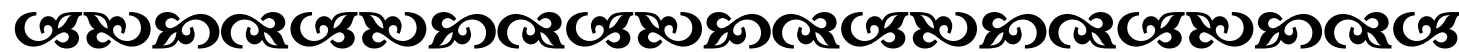

